\title{
PENGARUH KEPEMIMPINAN DAN MOTIVASI KERJA TERHADAP PRODUKTIVITAS KERJA KARYAWAN BAGIAN PRODUKSI PADA PT. TRIMURI KARYA CIPTA
}

\author{
Oleh : \\ Meindro Waskito dan Maelani Indah Kartini
}

\begin{abstract}
ABSTRAK
Tujuan penelitian ini untuk mengetahui terdapat pengaruh kepemimpinan dan motivasi kerja terhadap produktivitas kerja karyawan bagian produksi PT. Trimuri Karya Cipta. Adapun teknik pengumpulan data menggunakan kuisoner dengan skala likert, dengan populasi sebanyak 50 karyawan bagian produksi sebagai sample jenuh yang digunakan. Pengujian instrumen kuisoner dilakukan dengan uji validitas dan uji reliabilitas dan disebarkan kembali untuk diolah dan dianalisis. Hasil penelitian disini dengan uji hipotesis ( uji t ) menghasilkan thitung $=3,476>$ ( lebih besar ) $\mathrm{t}$ tabel $=2,011$ dan tingkat signifikan 0,001 < ( lebih kecil ) 0,05 yang diartikan bahwa Ho ditolak Ha diterima maka kepemimpinan (X1) terdapat pengaruh dan signifikan terhadap produktivitas kerja (Y) karyawan bagian produksi pada PT. Trimuri Karya Cipta. Sedangkan uji hipotesis ( uji t ) ) antara motivasi kerja (X2) terhadap produktivitas kerja ( Y ) menghasilkan thitung sebesar 2,094 > (lebih besar ) $t$ tabel $=2,011$ dengan tingkat signifikan $0,042<$ ( lebih kecil ) 0,05 yang diartikan bahwa Ho ditolak Ha diterima maka motivasi kerja (X2) terdapat pengaruh dan signifikan terhadap produktivitas kerja (Y) karyawan bagian produksi pada PT. Trimuri Karya Cipta.
\end{abstract}

Kata kunci : Kepemimpinan, Motivasi Kerja, Produktivitas Kerja

\section{ABSTRACT}

The purpose of this study was to determine the influence of leadership and work motivation on work productivity of employees in the production division of PT. Trimuri Cipta Karya. The data collection technique uses a questionnaire with a Likert scale, with a population of 50 employees of the production department as the saturated sample used. Testing of the questionnaire instrument was carried out by testing the validity and reliability testing and then redistributing it to be processed and analyzed. The results of the research here with hypothesis testing ( $t$ test) produce t count $=3,476>$ (larger) $t$ table $=2,011$ and a significant level of $0.001<($ smaller $)$ 0.05 which means that Ho is rejected Ha is accepted then leadership (XI) has an influence and significant to the work productivity $(Y)$ of employees in the production department at PT. Trimuri Cipta Karya. While the hypothesis test ( $t$ test)) between work motivation (X2) on work productivity $(Y)$ resulted in a t count of $2.094>$ (larger) $t$ table $=2.011$ with a significant level of $0.042<$ (smaller) 0.05 which means that Ho rejected Ha is accepted then work motivation (X2) has a significant and the effect on work productivity $(Y)$ of employees in the production division at PT. Trimuri Cipta Karya.

\section{Keywords: Leadership, Work Motivation, Work Productivity}




\section{Latar Belakang}

Peranan sumber daya manusia dari dahulu hingga sekarang ini merupakan faktor terpenting sebagai penggerak dalam melaksanakan seluruh kegiatan dalam mencapai tujuan perusahaan yang diinginkan. Kreatifitas dan inovasi sangat dibutuhkan pada peningkatan kualitas sumber daya manusia yang berkesinambungan, namun dilapangan sering dihadapkan dengan berbagai kendala dalam menghadapi persaingan yang begitu ketat. Apalagi situasi sekarang ini mengalami berbagai krisis akibat pandemi Covid 19. Kesulitan yang mendasar adalah menyatukan kebutuhan dan keinginan karyawan dengan kepentingan perusahaan. Maka sangat terlihat berbagai kegiatan yang dilakukan mempunyai dampak yang dirasakan dari seluruh aktifitas organisasi, termasuk perusahaan dan lain - lain terhadap seluruh aktifitas perusahaan dalam peningkatan produktifitas kerja karyawan, termasuk PT. Trimuri Karya Cipta.

PT. Trimuri Karya Cipta bediri sejak tahun 2006 yang berada di Jl. Canadian Broadway, Kawasan Pergudangan Commpark B-03 Kota Wisata Cileungsi, Bogor. Perusahaan ini merupakan perusahaan SPM (Special Purpose Machine) yang bergerak dibidang Kontraktor Mesin. Perusahaan ini memproduksi mesin sesuai dengan permintaan Customers dan menyesuaikan dengan kebutuhan yang mereka butuhkan. PT. Trimuri Karya Cipta akan selalu berusaha menjaga kualitas barang mesin yang diproduksi dan menjaga hubungan yang baik dengan Customers. Sehingga pemanfaatan karyawan yang ada agar bersedia bekerja keras untuk perusahaan sangat diperlukan, namun kenyataannya produktivitas kerja karyawan masih fluktuasi stabil atau belum ada peningkatan yang berarti.

Keberhasilan perusahaan dalam mempengaruhi produktivitas kerja karyawan, maka perusahaan harus selalu dapat mengintegrasikan atau menyatukan keinginan karyawan dengan perusahaan untuk menggapai tujuan perusahaan yang diinginkan perusahaan. Perusahaan terus berupaya dalam meningkatkan produktivitas kerja karyawannya, tetapi didalam perusahaan yang ada muncul berbagai kendala atau masalah baik itu masalah internal maupun masalah eksternal. Begitu pula dengan PT. Trimuri Karya Cipta yang juga memiliki masalah mengenai produktivitas kerja karyawan, seperti yang tertera pada laporan produksi sebagai berikut :

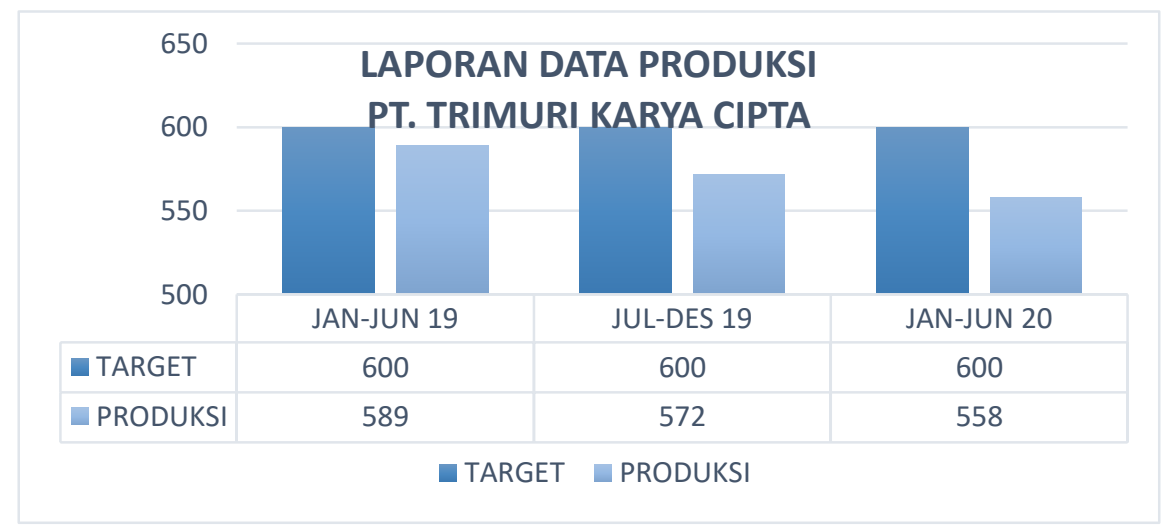

Gambar : Data Produksi Pt. Trimuri Karya Cipta, di Olah.

Dari gambar terlihat bahwa PT. Trimuri Karya Cipta khususnya pada bagian produksi terdapat masalah pada produktifitas kerja dari laporan produksi diatas, dimana 
pencapaian hasil produksi tidak mencapai target produksi yang telah ditetapkan sebesar 600 pcs persemester. Sehingga penurunan tingkat produksi, terlihat pada data per semester I ( januari-juni 2019) jumlah produksi sebesar 589 pcs, dengan produktivitas kerja yang dicapai sebesar 98\% dan pada semester II ( juli-desember 2019 ) jumlah produksi sebesar 572 pcs, ada penurunan produktivitas kerja yang dicapai sebesar 95\%, sedangkan pada semester III ( januari-juni 2020 ) terjadi penurunan kembali dengan jumlah produksi 558 pcs, dengan hasil produktivitas kerja hanya sebesar 93\%.

Dari hasil produktivitas kerja karyawan per semester pada periode Januari 2019 sampai juni 2020 dapat dilihat bahwa adanya penurunan pada tingkat produksi, dimana tidak mencapai target produksi yang ditetapkan oleh perusahaan. Hal ini didukung dengan wawancara yang diterima HRD menyatakan bahwa penurunan produktivitas kerja karyawan disebabkan bahwa salah satunya adalah kontribusi karyawan yang lagi menurun karena hubungan antara atasan dengan karyawan dan sesama karyawan yang kurang harmonis, sehingga motivasi kerja dalam mencapai prestasi belum tumbuh dengan baik. Berikut persepsi karyawan dengan kepemimpinan belum menyatu secara baik, sehingga visi dan misi serta tujuan perusahaan tidak terlaksana dengan maksimal.

Kemudian wawancara dengan beberapa karyawan PT. Trimuri Karya Cipta, untuk melakukan kajian yang mendalam mengenai faktor-faktor yang menyebabkan tingkat produktivitas kerja yang menurun, dimana penurunan produktivitas kerja diketahui $40 \%$ dipengaruhi oleh kepemimpinan, 35\% dipengaruhi motivasi kerja, dan faktor lainnya sebesar 25\%. Fenomena dalam meningkatkan produktivitas kerja dari setiap karyawannya, banyak mengalami kesulitan karena menyamakan persepsi karyawan bersama perusahaan atau pimpinan perusahaan harus bisa memahami sifat dan motif karyawan dengan memberikan sebuah motivasi kerja yang baik kepada seluruh karyawannya dalam meningkatkan produktifitas kerja atau hasil produksi yang tinggi sesuai dengan tujuan perusahaan. Sehingga kepemimpinan yang efektif, harus bisa memberikan dorongan atau motivasi kerja baik secara internal maupun eksternal kepada karyawannya dalam upaya peningkatan produktivitas kerja.

Seorang pemimpin dalam peningkatan Produktivitas kerja karyawan diatas tidaklah mudah, karena motivasi kerja karyawan juga berbeda - beda. Perusahaan sendiri dalam melihat banyak faktor yang harus diperhatikan, telah ada berbagai upaya yang dilakukanya seperti pemberian kompensasi, penghargaan dan lain - lain telah sesuai dengan peraturan yang ada. Perusahaan atau pimpinan sering memberikan memotivasi individu yang berkerja agar menghasilkan produktifitas kerja yang diharapkan. Masalahnya kadang individu memiliki kejenuhan dalam melaksanakan tugasnya, karena kebutuhan masing - masing karyawan berbeda - beda. Sehingga motivasi kerja untuk meningkatkan produktivitas kerja yang baik secara internal maupun eksternal sangat diperlukan. Kunci untuk mendorong motivasi kerja karyawan adalah bagaimana memahami apa yang dibutuhkan dan diinginkan oleh mereka. Sedangkan pemimpin perusahaan mempunyai harapan yang besar, agar karyawannya dapat selalu meningkatkan produktifitas kerja yang lebih baik, dikarenakan kepemimpinan seorang pemimpin harus bisa mendorong karyawannya secara lebih efektif dan efisien dalam melakukan tanggung jawab terhadap pekerjaannya.

Demikian uraian latar belakang diatas, maka penulis tertarik untuk melakukan penelitian dengan tujuan penelitian, yaitu :

1. Untuk mengetahui terdapat pengaruh kepemimpinan terhadap produktivitas kerja karyawan PT. Trimuri Karya Cipta. 
2. Untuk mengetahui terdapat pengaruh motivasi kerja terhadap produktivitas kerja karyawan PT. Trimuri Karya Cipta.

\section{Tinjauan Pustaka \\ Pengertian Produktivitas Kerja}

Keberhasilan kinerja individu ( karyawan ), kelompok dan organisasi terletak pada produktifitasnya. Menurut Wibowo ( 2016 ) produktifitas adalah hubungan antara keluaran atau hasil organisasi dengan masukan yang diperlukan. Adapun tipe produktifitas yang dimaksud ada dua tipe, yaitu total productivity adalah rasio yang menghubungkan nilai semua keluaran dengan nilai semua masukan dan partial productivity adalah rasio yang menghubungkan nilai semua keluran dengan nilai kategori utama masukan. Sehingga produktivitas kerja merupakan partial productivity yang dapat diartikan sebagai hubungan atau keterkaitan antara semua keluaran ( hasil produksi ) dengan nilai kategori utama masukan ( yaitu tenaga kerja ). Secara teknis produktivitas kerja merupakan antara hasil output yang dicapai dengan keseluruhan sumber daya manusia yang dipergunakan. Menurut Sutrisno (2011) menyatakan bahwa setiap perusahaan selalu berkeinginan agar karyawan atau tenaga kerja yang dimiliki mampu mendorong produktivitas kerja yang tinggi. Hal ini berasumsi bahwa keberhasilan perusahaan sangat tergantung pada efektifitas dan efisiensi penggunaan sumber daya manusia, karena perusahaan diharapkan selalu ingin meningkatkan produktivitas kerja karyawan guna mencapai tujuan yang direncanakan sebelumnya.

Banyak factor yang mempengaruhi peningkatan produktifitas kerja karyawan, namun fenomena perusahaan PT. Trimuri Karya Cipta lebih di dominasi oleh factor kepemimpinan dan motivasi kerja. Menurut Wibowo ( 2016, 98 ) tantangan mencapai produktifitas adalah ditemukan pemimpin - pemimpin local tidak memahami dengan baik gagasan - gagasan dalam meningkatkan produktifitas kerja karyawannya. Hal ini karena kepemimpinan seorang pemimpin kurang komunikasi dan berinteraksi dengan para supervisor, apalagi dengan karyawan sebagai bawahannya. Apalagi karyawannya tidak dapat diperlakukan sekehendak hati oleh seorang pemimpin, berbeda dengan masukan lainnya seperti mesin, modal, metode dan material. Oleh karena itu kepemimpinan seorang pemimpin perlu mempengaruhi sikap dan perilaku karyawan dengan memotivasi karyawannya. Sehingga motivasi kerja juga ikut mempengaruhi peningkatan produktifitas kerja karyawan, karena meningkatnya motivasi kerja karyawan akan meningkatkan kinerja individu, kelompok maupun organisasi sesuai tujuan perusahaan.

Sedangkan Sedarmayanti ( 2018) mengemukakan bahwa produktivitas kerja merupakan hal yang sangat penting bagi para karyawan yang ada diperusahaan, dengan adanya produktivitas kerja diharapkan pekerjaan terlaksana secara efektif dan efisien, karena kinerja karyawan meningkat belum tentu produktifitas kerja karyawan meningkat. Sehingga produktifitas kerja karyawan sangat diperlukan dan sangat penting dalam pencapaian tujuan yang sudah ditetapkan, karena kalau produktifitas kerja meningkat ada kecenderungan kinerja karyawan meningkat pula ( lebih efektif dan efisien ). Oleh karena itu produktivitas kerja adalah ukuran kemampuan dalam menghasilkan keluaran atau barang dari masukan berbagai factor produksi atau sumber daya khususnya sumber daya manusia yang digunakan untuk meningkatkan kualitas dan kuantitas pekerjaan yang dihasilkan dalam suatu perusahaan. Dengan demikian kedua faktor kepemimpinan dan motivasi kerja, sebagai masukan dapat mempengaruhi 
produktifitas kerja karyawannya, yang mana efektivitas dan kualitas keluaran (output) yang dicapai sesuai dengan tujuan ditetapkan oleh perusahaan.

Oleh karena itu indikator produktifitas kerja, menurut Simamora, ( 2011) menyatakan bahwa factor - faktor yang digunakan dalam pengukuran produktivitas kerja adalah :

1. Kuantitas kerja, merupakan suatu hasil pekerjaan ( output) yang dicapai oleh karyawan dalam jumlah tertentu dengan perbandingan standar yang ada atau ditentukan oleh perusahaan.

2. Kualitas kerja adalah merupakan suatu standar hasil yang berkaitan dengan kualitas dari suatu produk yang dihasilkan, karena merupakan suatu kemampuan karyawan dalam menyelesaikan pekerjaan secara teknis dengan di perbandingkan standar yang ditentukan oleh perusahaan.

3. Ketepatan waktu merupakan tingkat suatu aktivitas yang dapat diselesaikan pada awal waktu yang ditentukan, dengan diukur dari persepsi karyawan terhadap suatu aktivitas yang disediakan diawal waktu sampai menjadi output yang ditetapkan oleh perusahaan.

\section{Pengertian Kepemimpinan}

Kepemimpinan merupakan suatu proses yang mempengaruhi seseorang ( orang lain ), kelompok atau organisasi dalam mencapai tujuan perusahaan. Faktor kepemimpinan memegang peranan yang penting karena seorang pemimpin itulah yang dapat menggerakkan dan mengarahkan sebuah organisasi dalam mencapai tujuan dan sekaligus merupakan tugas yang tidak mudah, karena seorang pemimpin harus mampu mengambil setiap keputusan berdasarkan fakta dan peraturan yang ada diperusahaan serta memahami setiap sikap dan perilaku bawahan yang berbeda - beda pula. Beberapa ahli mengemukakan definisi mengenai pemimpin diantaranya adalah (Amirullah, 2015) orang yang memiliki wewenang untuk memberi tugas mempunyai kemampuan untuk membujuk ( persuasive) atau mempengaruhi orang lain dengan melalui pola hubungan yang baik guna mencapai tujuan organisasi yang telah ditentukan. Sedangkan menurut Sondang P. Siagian ( 2014) mengemukakan bahwa kepemimpinan ialah sebuah aktivitas kemampuan seseorang yang dapat mempengaruhi orang lain atau bawahannya, sedemikian rupa agar orang lain itu mau dan mampu melakukan kehendak pemimpin meskipun secara pribadi hal itu mungkin tidak disenanginya.

Seorang pemimpin didalam menjalankan tugasnya akan berperan sebagai figure yang dapat menggerakan bawahannya atau karyawannya agar memenuhi kewajibannya dengan inovasi dan kreatif dalam membina, melatih, mempengaruhi, mendorong, mengambil setiap keputusan dan juga mengevaluasi serta mampu dalam menyelesaikan masalah yang pada akhirnya dapat meningkatkan produktifitas kerja. Keberhasilan dalam pencapaian tujuan tersebut tentunya harus diimbangi oleh individu - individu yang mempunyai motivasi kerja dalam perusahaan. Sehingga kegiatan individu yang bekerja bersama-sama pemimpinnya, dimana pemimpin memberikan tugas atau perintah dan tanggung jawab kepada karyawannya untuk dapat menyelesaikan pekerjaan sesuai dengan targetnya.

Sehingga kepemimpinan yang diperankan oleh seorang pemimpin. memiliki indikator - indicator dalam kepemimpinan menurut Sunyoto ( 2015) adalah sebagai berikut : 
1) Pemberi motivasi, dimana pemimpin harus mampu berkomunikasi dengan baik dan lancer dalam memberi dorongan atau memberikan motivasi kepada bawahannya, baik motivasi secara internal maupun eksternal.

2) Cara berkomunikasi, dimana pemimpin harus mampu dan tahu cara berkomunikasi dengan baik dan lancar dengan memberikan sebuah informasi yang jelas, dan bertanggung jawab.

3) Kemampuan memimpin, yaitu berkenaan dengan bakat atau kemampuan seseorang, dalam gaya kepemimpinan.

4) Pengambil keputusan, dimana pemimpin harus mampu mengambil keputusan dengan fakta dilapangan dengan peraturan yang berlaku diperusahaan, dan harus mampu memberikan motivasi bagi karyawan untuk bekerja lebih baik.

Berdasarkan indikator kepemimpinan tersebut, seorang pemimpin harus mampu memberikan motivasi, cara berkomunikasi, dan mampu memimpin serta pengambilan keputusan dalam rangka meningkatkan produktifitas kerja karyawannya.

\section{Pengertian Motivasi Kerja}

Banyak pengertian motivasi, salah satunya adalah keinginan untuk bertindak. Oleh karena itu motivasi kerja karyawan terbentuk dari seluruh sikap atau perilaku karyawan dalam bertindak dan menghadapi lingkungan pekerjaan, dimana motivasi kerja merupakan proses situasi dan kondisi dalam mendorong karyawan agar dapat bertindak mencapai tujuan perusahaan. Seperti Hasibuan (2015) mengemukakan bahwa motivasi kerja merupakan situasi dan kondisi dengan energi yang menggerakkan diri karyawan yang terarah atau tertuju dalam mencapai tujuan perusahaan. Maka pemberian motivasi kerja kepada karyawan merupakan kewajiban para pemimpin perusahaan, agar karyawan tersebut dapat meningkatkan jumlah dan kualitas pekerjaan yang menjadi tanggung jawabnya. Sehingga motivasi seorang dalam bekerja muncul karena dorongan perlunya bertindak untuk memenuhi kebutuhan produktifitas kerja yang diinginkannya.

Menurut Coleman Patterson ( 2010, 51 ) bahwa pengertian motivasi adalah apa yang membangkitkan, mengarahkan, dan mempertahankan sikap dan perilaku. Adapun menurut Stephen F. Robbins dan Mary Coulter ( 2012, 410 ) berpendapat bahwa motivasi mengacu pada proses dimana upaya seseorang diberi energy dan diarahkan secara berkelanjutan ( ketekunan ) untuk mencapai suatu tujuan. Sedangkan Sutrisno ( 2010, 116-118 ) menjelaskan motivasi terdiri dari motivasi internal adalah suatu dorongan yang berasal dari dalam diri seseorang, dan motivasi eksternal adalah suatu dorongan atau kekuatan yang berasal dari luar, yang dapat mengendalikan seseorang. Sehingga motivasi kerja yang dimaksud mempunyai indikator, yaitu :

1. Motivasi Internal, antara lain :

a. Tanggung jawab pegawai dalam melaksanakan tugas

b. Melaksanakan tugas dengan target yang jelas

c. Ada umpan balik atas hasil pekerjaannya

d. Memiliki tujuan yang jelas dan menantang

e. Memiliki perasaan senang dalam bekerja

f. Selalu berusaha untuk mengungguli orang lain

g. Diutamakan prestasi dari apa yang dikerjakan

2. Motivasi Eksternal, antara lain :

a. Selalu berusaha untuk memenuhi kebutuhan hidup dan kebutuhan kerjanya

b. Senang memperoleh pujian / penghargaan dari apa yang dikerjakannya

c. Bekerja dengan harapan ingin memperoleh tunjangan atau insetif 
d. Bekerja dengan harapan ingin memperoleh perhatian dari teman dan atau atasan

Sehingga motivasi kerja merupakan hal yang sangat penting terhadap sumber daya manusia, agar tetap dan mau bertindak melaksanakan pekerjaan ( misi dan tujuan ) lembaga sesuai dengan kemampuan yang mereka miliki dengan ikhlas dan sepenuh hati. Dengan demikian bahwa motivasi kerja seorang karyawan muncul karena dorongan bertindak untuk memenuhi kebutuhan yang diinginkan baik secara internal maupun ekternal, dengan elemen kunci memiliki energy yang membangkitkan, arah sikap dan perilaku dan ketekunan guna mencapai suatu tujuan yang diinginkan perusahaan.

\section{Kerangka Pemikiran}

\section{Hubungan Kepemimpinan terhadap Produktivitas Kerja Karyawan}

Kepemimpinan adalah cara seorang pemimpin dalam mempengaruhi sikap dan perilaku bawahan, agar mau mau menyatu dan bekerjasama secara produktif. Dimana kepemimpinan seorang pemimpin merupakan sebuah proses mempengaruhi dalam menggerakkan seluruh karyawan untuk saling berinteraksi satu sama lain dan terintegrasi dalam upaya untuk mencapai tujuan perusahaan. Kepemimpinan yang ideal harus bisa menciptakan integrasi yang serasi, selaras dan seimbang dalam mendorong gairah kerja karyawan dalam mempengaruhi produktivitas kerja karyawan, karena seluruh karyawan membutuhkan figure seorang pemimpin dalam meraih keberhasilan sebuah perusahaan. Pada dasarnya kemampuan pemimpin sangat diharapkan dalam menerapkan kepemimpinannya untuk mengelola atau mengendalikan bawahannya, agar berhasil dan sukses dalam mencapai tujuannya. Dimana pemimpin adalah seseorang yang menggunakan wewenang dan kepemipinannya bias menggerakkan bawahan dalam meningkatkan produktivitas kerja karyawannya. Dimana produktivitas kerja dapat dilihat berdasarkan tolak ukur masing-masing, dalam hasil kerja karyawan baik dari segi jumlah, kualitas dan ketepatan waktu dalam menyelesaikan aktifitas pekerjaannya.

Michael Armstrong ( 2016, 4 ) berpendapat bahwa, kepemimpinan adalah proses untuk membuat orang melakukan yang terbaik untuk mencapai hasil atau tujuan yang diharapkan. Dimana kepemimpinan yang ideal harus dimiliki setiap pemimpin harus bersikap bias mengayomi sebagai penggerak yang mendorong, menuntun dan membimbing dalam peningkatan produktifitas kerja karyawannya, karena semakin baik kepemimpinan yang diterapkan maka semakin baik pula dalam peningkatan produktivitas kerja karyawan sesuai tujuan yang diinginkan oleh perusahaan. Sehingga kepemimpinan yang diterapkan oleh seorang pemimpin harus efektif dan efisien, karena memotivasi karyawan sering tidak mudah dalam menggerakkan atau bertindak dan berperilaku dalam rangka mencapai produktifitas kerja dan tujuan perusahaan. Maka dari itu hipotesa pertama adalah sebagai berikut :

H1 : Terdapat pengaruh antara Kepemimpinan terhadap Produktivitas Kerja karyawan.

\section{Hubungan Motivasi Kerja terhadap Produktivitas Kerja Karyawan}

Motivasi kerja sangat diperlukan dalam memberikan dorongan atau semangat seseorang untuk melakukan segala aktifitas dalam pekerjaan dalam mencapai tujuan perusahaan. Dalam teori klasik motivasi kerja seseorang dalam melakukan kegiatan muncul karena merasa ingin untuk memenuhi kebutuhannya. Abraham Maslow dalam Wibowo (2016, 323 ) mengembangkan Hierarchy of Need Teory dan mengelompokkan motivasi dalam lima tingkatan, yaitu kebutuhan physiological (fisiologis), safety (rasa 
aman), social (hubungan social), esteem (penghargaan), dan self actualization (aktualisasi diri). Kemudian dikembangkan oleh Frederick Herzberg dalam Two Factor Theory berdasarkan pada " motivators " dan " hygiene factor ". Dimana motivators sesungguhnya untuk mendorong seseorang untuk mendapatkan kebutuhannya, terdiri dari : achievement ( prestasi ), recognition ( pengakuan ), job interest ( minat pada pekerjaan ), responsibility ( tanggung jawab ) dan advancement ( Kemajuan ). Sehingga motivasi kerja yang terjadi merupakan motivasi seseorang pada situasi dan kondisi suatu perusahaan untuk mencapai produktifitas kerja karyawan yang diinginkan oleh perusahaan. Maka karyawan akan terdorong dengan sendirinya oleh motivasi dalam bekerja yang tumbuh dari dalam ( internal ) maupun dari luar ( external ) diri seseorang, yang mana akan meningkatkan produktifitas kerja karyawannya.

Motivasi dalam bekerja yang tumbuh dan berkembang dengan sendirinya akan mendorong atau memberikan semangat bekerja dalam mencapai tujuan perusahaan. Hal ini perlu adanya upaya untuk mempertahankan dan bahkan meningkatkan motivasi kerja, sehingga akan berdampak baik terhadap peningkatan produktivitas kerja karyawan dimasa mendatang. Motivasi kerja dalam perusahan sangatlah membantu untuk meningkatkan produktivitas kerja karyawan, dimana karyawan akan selalu termotivasi apabila kebutuhan dan keinginan karyawan dapat terpenuhi. Hal ini dapat diperkuat dengan adanya teori dari Hasibuan, 2015) mengatakan bahwa motivasi kerja sangat penting karena dengan motivasi kerja ini diharapkan setiap individu atau karyawan mau bekerja keras dan antusias untuk mencapai produktivitas yang tinggi. Maka produktivitas kerja yang tinggi bisa diperoleh jika didukung para karyawan yang mempunyai motivasi kerja, atau sebaliknya. Dengan demikian peningkatan motivasi kerja berpengaruh terhadap peningkatan produktivitas kerja karyawan, begitu sebaliknya. Maka dari itu hipotesa kedua adalah sebagai berikut :

H2 : Terdapat pengaruh antara Motivasi kerja terhadap Produktivitas kerja karyawan.

Dengan demikian keterkaitan antar variable kepemimpinan ( X1 ), motivasi kerja ( X2 ), terhadap produktifitas kerja ( Y ), dapat digambarkan dengan model kerangka pemikiran sebagai berikut :

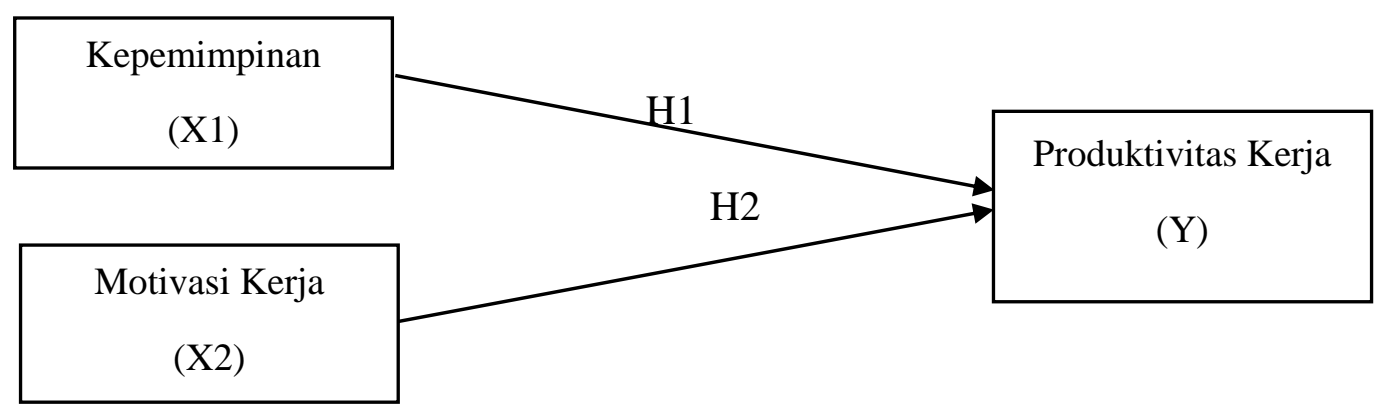

Gambar : Kerangka pemikiran

\section{Metode Penelitian}

Metode dalam pengumpulan data menggunakan wawancara dan kuisoner dengan skala likert, yang berisi pernyataan dengan uji validitas dan realibilitas. Kuisoner disebarkan pada populasi karyawan PT. Trimuri Karya Cipta bagian produksi yang berjumlah 50 karyawan, menggunakan sampling jenuh. Adapun teknik analisa data menggunakan teknik analisis regresi sederhana, yang sebelumnya terlebih dahulu 
dilakukan uji asumsi klasik sebagai persyaratan dalam sebuah analisis agar datanya dapat dianalisis secara meyakinkan.

Adapun variabel dan pengukuran berdasarkan definisi operasional, sebagai berikut :

Produktivitas Kerja (Y), merupakan kemampuan menghasilkan barang yang diproduksi dibandingkan dengan keseluruhan sumber daya manusia yang dipergunakan, baik kualitas pekerjaan dan ketepatan waktu yang sudah ditetapkan.

Kepemimpinan (X1), merupakan suatu proses yang mempengaruhi seseorang, kegiatan suatu kelompok, dalam memberi motivasi untuk menuju arah pencapain sebuah tujuan dan mampu mengambil keputusan berdasarkan peraturan yang berlaku.

Motivasi kerja (X2), merupakan dorongan memenuhi kebutuhan baik secara internal dan eksternal dalam melakukan pekerjaan sesuai dengan target yang jelas.

Berikut adalah kisi - kisi variable berdasarkan variable, sub variable ( dimensi ), indikator yang telah ditetapkan dan nomor instrument berdasarkan hasil uji validitas, sebagai berikut :

\section{Kisi - Kisi Variabel}

\begin{tabular}{|c|c|c|c|c|}
\hline No & Variabel & $\begin{array}{c}\text { Sub } \\
\text { Variabel }\end{array}$ & Indikator & $\begin{array}{c}\text { Skala } \\
\text { Pengukuran }\end{array}$ \\
\hline \multirow[t]{4}{*}{1.} & \multirow[t]{4}{*}{$\begin{array}{l}\text { Produktivitas } \\
\text { Kerja (Y) }\end{array}$} & \multirow[t]{2}{*}{ 1.Kualitas kerja } & $\begin{array}{l}\text { 1.Mampu menyelesaikan } \\
\text { pekerjaan }\end{array}$ & $1,2,3,4$ \\
\hline & & & $\begin{array}{l}\text { 2.Sesuai dengan standar } \\
\text { yang ditetapkan }\end{array}$ & $5,6,7,8$ \\
\hline & & \multirow[t]{2}{*}{$\begin{array}{l}\text { 2.Ketetapan } \\
\text { waktu }\end{array}$} & $\begin{array}{l}\text { 1.Aktivitas penyelesaian } \\
\text { diawal waktu }\end{array}$ & $9,10,11,12$ \\
\hline & & & $\begin{array}{l}\text { 2.Koordinasi dalam } \\
\text { memaksimalkan waktu }\end{array}$ & $13,14,15,16$ \\
\hline \multirow[t]{4}{*}{2.} & \multirow[t]{4}{*}{$\begin{array}{l}\text { Kepemimpinan } \\
\text { (X1) }\end{array}$} & \multirow[t]{2}{*}{$\begin{array}{r}\text { 1.Pemberi } \\
\text { Motivasi }\end{array}$} & $\begin{array}{l}\text { 1.Kemampuan Komunikasi } \\
\text { yang baik dan lancar. }\end{array}$ & $1,2,3,4$ \\
\hline & & & $\begin{array}{l}\text { 2.Kemampuan memberi } \\
\text { dorongan dan memberi } \\
\text { motivasi pada bawahan }\end{array}$ & $5,6,7$ \\
\hline & & \multirow[t]{2}{*}{$\begin{array}{l}\text { 2.Pengambil } \\
\text { Keputusan }\end{array}$} & $\begin{array}{l}\text { 1.Pengambilan keputusan } \\
\text { berdasarkan fakta dan } \\
\text { peraturan yang berlaku }\end{array}$ & $8,9,10,11$ \\
\hline & & & $\begin{array}{l}\text { 2.Keputusan mampu } \\
\text { memberikan motivasi bagi } \\
\text { karyawan }\end{array}$ & $12,13,14,15$ \\
\hline \multirow[t]{3}{*}{3.} & \multirow[t]{3}{*}{$\begin{array}{l}\text { Motivasi } \quad \text { Kerja } \\
(\mathrm{X} 2)\end{array}$} & \multirow[t]{2}{*}{$\begin{array}{l}\text { 1.Motivasi } \\
\text { Internal }\end{array}$} & $\begin{array}{l}\text { 1.Tanggung jawab pegawai } \\
\text { dalam melaksanakan } \\
\text { tugas }\end{array}$ & $1,2,3,4,5$ \\
\hline & & & $\begin{array}{l}\text { 2.Melaksanakan tugas } \\
\text { dengan target yang jelas }\end{array}$ & $6,7,8,9,10$ \\
\hline & & $\begin{array}{l}\text { 2.Motivasi } \\
\text { External }\end{array}$ & $\begin{array}{l}\text { 1.Selalu berusaha untuk } \\
\text { memenuhi kebutuhan } \\
\text { hidup dan kebutuhan } \\
\text { kerjanya. }\end{array}$ & $11,12,13,14$ \\
\hline
\end{tabular}




\begin{tabular}{|l|l|l|l|l|}
\hline & & $\begin{array}{l}\text { 2.Senang memperoleh } \\
\text { pujian dari apa yang } \\
\text { dikerjakan. }\end{array}$ & $15,16,17$ \\
\hline
\end{tabular}

\section{Hasil Analisis dan Pembahasan}

\section{Kepemimpinan (X1) Terhadap Produktivitas Kerja Karyawan (Y)}

Dalam variabel kepemimpinan (X1) terhadap variabel produktivitas kerja (Y), melalui program SPSS, diperoleh hasil sebagai berikut :

\section{Tabel : Koefisien Regresi Sederhana Antara X1 dan Y}

\section{Coefficients $^{\mathrm{a}}$}

\begin{tabular}{|l|l|r|r|r|r|r|}
\hline \multirow{2}{*}{ Model } & \multicolumn{2}{|c|}{$\begin{array}{c}\text { Unstandardized } \\
\text { Coefficients }\end{array}$} & $\begin{array}{c}\text { Standardized } \\
\text { Coefficients }\end{array}$ & \multirow{2}{*}{$\mathrm{t}$} & \multirow{2}{*}{ Sig. } \\
\cline { 2 - 6 } & $\mathrm{B}$ & $\begin{array}{c}\text { Std. } \\
\text { Error }\end{array}$ & \multicolumn{2}{|c|}{ Beta } & & \\
\hline \multirow{2}{*}{1} & (Constant) & 49.315 & 4.561 & & 10.811 & .000 \\
\cline { 2 - 6 } & Kepemimpinan & .286 & .082 & .448 & 3.476 & .001 \\
\hline
\end{tabular}

Sumber : Hasil olah data SPSS, 2020.

Dari tabel koefisien regresi sederhana antara kepemimpinan (X1) terhadap variabel produktivitas kerja (Y), diperoleh persamaan regresi sebagai berikut : $\mathrm{Y}=49,315+$ $0,286 \mathrm{X} 1$.

Persamaan di atas dapat diartikan sebagai berikut :

a. $\quad \alpha=49,315$. Persamaan regresi tersebut memiliki nilai pada konstanta yaitu 49,315 yang menyatakan bahwa apabila tidak ada kenaikan pada variabel Kepemimpinan, maka nilai variabel Produktivitas Kerja adalah 49,315.

b. $\beta=0,286$. Artinya apabila variabel Kepemimpinan (X1) meningkat satu satuan dan variabel lainnya dianggap konstan, maka variabel Produktivitas Kerja (Y) meningkat sebesar 0,286 satuan.

Berikut hasil perhitungan dari analisis koefisien korelasi sederhana dengan menggunakan SPSS, sebagai berikut : 
Tabel : Koefisien Korelasi Sederhana antara X1 terhadap Y Correlations

\begin{tabular}{|c|c|c|c|}
\hline & & Kepemimpinan & $\begin{array}{c}\text { Produktivitas } \\
\text { Kerja }\end{array}$ \\
\hline \multirow{3}{*}{ Kepemimpinan } & $\begin{array}{l}\text { Pearson } \\
\text { Correlation }\end{array}$ & 1 & $.448^{* *}$ \\
\hline & $\begin{array}{l}\text { Sig. (2- } \\
\text { tailed) }\end{array}$ & & .001 \\
\hline & $\mathrm{N}$ & 50 & 50 \\
\hline \multirow{3}{*}{$\begin{array}{l}\text { Produktivitas } \\
\text { Kerja }\end{array}$} & $\begin{array}{l}\text { Pearson } \\
\text { Correlation }\end{array}$ & $.448^{* *}$ & 1 \\
\hline & $\begin{array}{l}\text { Sig. (2- } \\
\text { tailed) }\end{array}$ & .001 & \\
\hline & $\mathrm{N}$ & 50 & 50 \\
\hline
\end{tabular}

Sumber : Hasil data SPSS, 2020

Hasil diatas dapat diketahui bahwa nilai pearson correlation (r) Kepemimpinan (X1) terhadap Produktivitas Kerja (Y) sebesar 0,448 hal ini menunjukkan bahwa adanya keeratan korelasi yang sedang. Adapun koefisien determinasi diperoleh dengan $r^{2}=($ $0,448)^{2}=0,2007$. Dimana nilai $\mathrm{r}^{2}$ sebesar 0,2007 atau 20,07\% yang artinya kepemimpinan (X1) memberikan sumbangan terhadap produktivitas kerja (Y) karyawan sebesar 20,07 \% maka masih banyak faktor lain mempengaruhi produktifitas kerja sebesar $79,93 \%$.

Untuk uji hipotesis menggunakan uji t untuk menguji signifikan secara parsial dari variabel kepemimpinan ( X1 ) terhadap variabel Produktivitas Kerja ( Y ). Adapun hasil uji t dapat dilihat pada table sebagai berikut :

Tabel : Uji t untuk kepemimpinan ( X1 ) terhadap produktifitas kerja (Y)

Coefficients $^{\mathrm{a}}$

\begin{tabular}{|c|c|c|c|c|c|c|}
\hline \multirow{2}{*}{\multicolumn{2}{|c|}{ Model }} & \multicolumn{2}{|c|}{$\begin{array}{l}\text { Unstandardized } \\
\text { Coefficients }\end{array}$} & \multirow{2}{*}{$\begin{array}{c}\begin{array}{c}\text { Standardized } \\
\text { Coefficients }\end{array} \\
\text { Beta }\end{array}$} & \multirow{2}{*}{$\mathrm{t}$} & \multirow{2}{*}{ Sig. } \\
\hline & & B & $\begin{array}{l}\text { Std. } \\
\text { Error }\end{array}$ & & & \\
\hline \multirow{2}{*}{1} & (Constant) & 49.315 & 4.561 & & 10.811 & .000 \\
\hline & Kepemimpinan & .286 & .082 & .448 & 3.476 & .001 \\
\hline
\end{tabular}

Berdasarkan perolehan t hitung sebesar 3,476 lebih besar dari t table ( $\mathrm{t}$ hitung 3,476 > t tabel 2,011) yang berarti bahwa variable kepemimpinan (X1) berpengaruh terhadap produktivitas kerja (Y) karyawan. Adapun taraf signifikan kepemimpinan sebesar 0,001 dimana tingkat signifikan $(0,001<0,05)$, maka dapat simpulannya bahwa Ho ditolak Ha diterima yang artinya kepemimpinan (X1) dapat berpengaruh dan signifikan terhadap produktivitas kerja (Y) karyawan pada PT. Trimuri Karya Cipta. 
Analisa diatas menggambarkan bahwa terdapat pengaruh secara partial dan signifikan antara variable kepemimpinan ( X1 ) terhadap variable produktivitas kerja ( Y ) karyawan pada PT. Trimuri Karya Cipta. Hal ini didukung perhitungan yang diketahui bahwa nilai koefisien korelasi sederhana adalah 0,448 hal ini menunjukan bahwa hubungan antara variabel Kepemimpinan (X1) terhadap produktivitas kerja Karyawan (Y) terjadi keeratan korelasi yang sedang. Sedangkan kontribusi variable kepemimpinan ( X1 ) hanya menunjukkan sebesar 0,2007 atau 20,07 \% yang artinya variabel kepemimpinan (X1) memberikan kontribusi terhadap produktivitas kerja (Y) karyawan sebesar 20,07 \% sedangkan banyak faktor lain sebesar 79,93\%. mempengaruhi produktifitas kerja karyawannya. Hal ini menunjukkan bahwa adanya banyak faktor lain diluar dari penelitian ini yang lebih dominan berpengaruh terhadap produktivitas kerja seperti motivasi kerja, disiplin kerja, budaya organisasi dan lain - lain yang tidak dilakukan dalam penelitian ini.

Pembahasan disini sudah sesuai dengan keadaan dimana kepemimpinan seorang pemimpin pada PT. Trimuri Karya Cipta, dimana kepemimpinan yang dilakukan cenderung memperlakukan manajemen lebih ke personal art dibandingkan dengan bagaimana kepemimpinan seorang pemimpin tidak semata -mata diarahkan dalam peningkatan produktifitas kerja karyawannya. Walaupun kepemimpinan yang diterapkan sudah berjalan dengan baik dan sesuai dengan harapan karyawan dalam mendukung produktivitas kerja karyawan, namun masih perlu ditingkatkan dengan mempertimbangkan berbagai factor yang mempengaruhinya. Dimana kepemimpinan yang baik akan sangat mempengaruhi terhadap produktifitas kerja karyawan, karena sesungguhnya kesuksesan atau keberhasilan perusahaan pada dasarnya terletak pada kemampuan pemimpinnya.

\section{Motivasi Kerja (X2) Terhadap Produktivitas Kerja Karyawan (Y)}

Berikut variabel motivasi kerja (X2) terhadap variabel produktivitas kerja (Y), melalui program SPSS, dengan hasil adalah sebegai berikut :

\section{Tabel : Analisis Regresi Sederhana Antara X2 dan Y}

\begin{tabular}{|c|c|c|c|c|c|c|}
\hline \multicolumn{7}{|c|}{ Coefficients $^{\mathrm{a}}$} \\
\hline \multirow{2}{*}{\multicolumn{2}{|c|}{ Model }} & $\begin{array}{r}\text { Unstanc } \\
\text { Coeff }\end{array}$ & $\begin{array}{l}\text { ardized } \\
\text { ients }\end{array}$ & $\begin{array}{l}\text { Standardized } \\
\text { Coefficients }\end{array}$ & \multirow{2}{*}{$\mathrm{t}$} & \multirow{2}{*}{ Sig. } \\
\hline & & B & $\begin{array}{l}\text { Std. } \\
\text { Error }\end{array}$ & Beta & & \\
\hline \multirow[b]{2}{*}{1} & (Constant) & 55.891 & 4.382 & & 12.753 & .000 \\
\hline & $\begin{array}{l}\text { Motivasi } \\
\text { Kerja }\end{array}$ & .199 & .095 & .289 & 2.094 & .042 \\
\hline
\end{tabular}

Sumber : Hasil data SPSS, 2020

Melihat hasil diatas, hasil analisis regresi sederhana antara motivasi kerja ( X2 ) dan produktifitas kerja ( $\mathrm{Y}$ ) diperoleh persamaan regresi : $\mathrm{Y}=55,891+0,199 \mathrm{X} 2$

Persamaan diatas bisa diartikan :

a. $\alpha=55,891$. Persamaan regresi tersebut memiliki nilai pada konstanta yaitu 55,891 yang menyatakan bahwa apabila tidak ada kenaikan pada variabel motivasi kerja, maka variabel produktivitas kerja karyawan adalah sebesar 55,891.

b. $\beta=0,199$. Artinya apabila variabel motivasi kerja (X2) meningkat satu satuan dan variabel lainnya dianggap konstan, maka variabel Y meningkat 0,199 satuan. 
Berikut hasil perhitungan analisis koefisien korelasi sederhana antara motivasi kerja (X2) terhadap Produktivitas Kerja (Y) dengan menggunakan SPSS sebagai berikut :

Tabel : Koefisien Korelasi Sederhana antara X2 terhadap Y

Correlations

\begin{tabular}{|c|c|c|c|}
\hline & & $\begin{array}{c}\text { Motivasi } \\
\text { Kerja }\end{array}$ & $\begin{array}{c}\text { Produktivitas } \\
\text { Kerja }\end{array}$ \\
\hline \multirow{3}{*}{$\begin{array}{l}\text { Motivasi } \\
\text { Kerja }\end{array}$} & $\begin{array}{l}\text { Pearson } \\
\text { Correlation }\end{array}$ & 1 & $.289^{*}$ \\
\hline & $\begin{array}{l}\text { Sig. (2- } \\
\text { tailed) }\end{array}$ & & .042 \\
\hline & $\mathrm{N}$ & 50 & 50 \\
\hline \multirow{3}{*}{$\begin{array}{l}\text { Produktivitas } \\
\text { Kerja }\end{array}$} & $\begin{array}{l}\text { Pearson } \\
\text { Correlation }\end{array}$ & $.289^{*}$ & 1 \\
\hline & $\begin{array}{l}\text { Sig. (2- } \\
\text { tailed) }\end{array}$ & .042 & \\
\hline & $\mathrm{N}$ & 50 & 50 \\
\hline
\end{tabular}

Hasil diatas dapat menunjukkan bahwa nilai koefisien correlation (r) motivasi kerja (X2) terhadap Produktivitas Kerja (Y) sebesar 0,289 yang berarti menunjukkan bahwa adanya korelasi yang rendah. Adapun koefisien determinasi diperoleh dengan $\mathrm{r}^{2}$ $=(0,289)^{2}=0,0835$. Karena nilai $\mathrm{r}^{2}$ sebesar 0,0835 atau $8,35 \%$ yang berarti variabel motivasi kerja (X2) memberikan sumbangan pengaruh terhadap Produktivitas kerja (Y) karyawan sebesar 8,35 \% sedangkan banyak faktor - faktor lain yang mempengaruhi produktifitas kerja sebesar 91,65\%.

Untuk itu uji hipotesis dengan menggunakan uji t untuk menguji signifikan secara parsial dari variabel motivasi kerja ( X2 ) terhadap variabel Produktivitas Kerja ( Y ). Adapun hasil uji t dapat dilihat pada table sebagai berikut :

Tabel : Uji t untukMotivasi Kerja ( X2 ) terhadap produktifitas kerja (Y)

\section{Coefficients $^{\mathrm{a}}$}

\begin{tabular}{|c|c|c|c|c|c|c|}
\hline \multirow{2}{*}{\multicolumn{2}{|c|}{ Model }} & \multicolumn{2}{|c|}{$\begin{array}{c}\text { Unstandardized } \\
\text { Coefficients }\end{array}$} & \multirow{2}{*}{$\begin{array}{c}\begin{array}{c}\text { Standardized } \\
\text { Coefficients }\end{array} \\
\text { Beta }\end{array}$} & \multirow{2}{*}{$\mathrm{t}$} & \multirow{2}{*}{ Sig. } \\
\hline & & B & $\begin{array}{l}\text { Std. } \\
\text { Error }\end{array}$ & & & \\
\hline \multirow[b]{2}{*}{1} & (Constant) & 55.891 & 4.382 & & 12.753 & .000 \\
\hline & $\begin{array}{l}\text { Motivasi } \\
\text { Kerja }\end{array}$ & .199 & .095 & .289 & 2.094 & .042 \\
\hline
\end{tabular}

Perolehan t hitung sebesar 2,094 menunjukkan lebih besar dari t table ( $\mathrm{t}$ hitung 2,094 > ttabel 2,011) yang artinya bahwa Motivasi Kerja ( X2 ) berpengaruh positif terhadap produktivitas kerja ( $\mathrm{Y}$ ) karyawan. Adapun taraf signifikan motivasi kerja sebesar 0,042 dimana tingkat signifikan $(0,042<0,05)$, maka dapat simpulannya bahwa Ho ditolak Ha diterima yang artinya Motivasi Kerja ( X2 ) terdapat pengaruh dan signifikan terhadap produktivitas kerja (Y) karyawan pada PT. Trimuri Karya Cipta. 
Hasil perolehan analisa data dan pengujian hipotesis dalam penelitian ini menunjukan bahwa secara parsial terdapat pengaruh dan signifikan antara motivasi kerja terhadap produktivitas kerja karyawan. Hal ini sesuai dengan hasil nilai koefisien korelasi sederhana sebesar 0,289, yang menunjukkan bahwa pengaruh antara variabel Motivasi Kerja (X2) terhadap Produktivitas Kerja (Y) terjadi keeratan korelasi yang rendah. Adapun kontribusi motivasi kerja ( X2 ) hanya berkisar 0,0835 atau sebesar 8, $35 \%$ yang artinya variabel motivasi kerja (X2) memberikan kontribusi terhadap produktivitas kerja (Y) karyawan sebesar 8,35 \% sedangkan banyak faktor lain sebesar 91,65 \% mempengaruhi produktifitas kerja karyawannya, seperti kepemimpinan, kompensasi dan lain - lain yang tidak dilakukan dalam penelitian ini.

Dengan demikian bahwa adanya faktor lain diluar dari penelitian ini yang lebih dominan berpengaruh terhadap produktivitas kerja. Dimana motivasi kerja yang tinggi menjadikan para karyawan memiliki semangat bekerja yang lebih tinggi, namun tidak diimbangi dengan factor lain, sehingga masih bisa mendorong secara lemah terhadap produktifitas kerja karyawannya. Memang agak krusial membahas produktifitas kerja karyawan, yang mana banyak factor lain yang mempengaruhi secara komprehensif, karena keterbatasan penelitian, maka upaya ini hanya melihat factor kepemimpinan dan motivasi kerja secara partial bahkan kalau perlu secara bersama - sama akan melihat lebih jauh dan lebih kuat pengaruhnya terhadap produktifitas kerja karyawannya. Sehingga upaya minimal disini masih dapat melihat dan mempertahankan motivasi kerja para karyawan dalam mempengaruhi produktifitas kerja karyawanya. agar tetap berada pada level yang bisa ditingkatkan kembali, sehingga akan berdampak positif bagi perkembangan karyawan dalam meningkatkan produktivitas kerja karyawan yang dihasilkan dimasa mendatang.

\section{Simpulan}

Berdasarkan hasil penelitian dan pembahasan yang telah dilakukan, dengan pengujian hipotesis menggunakan uji t dapat diperoleh simpulan :

1. Terdapat pengaruh dan signifikan antara variable kepemimpinan ( X1 ) terhadap variabel produktivitas kerja ( Y ) karyawan. pada PT. Trimuri Karya Cipta.

2. Terdapat pengaruh dan signifikan antara variable motivasi kerja $(\mathrm{X} 2)$ terhadap variable produktivitas Kerja Karyawan pada PT. Trimuri Karya Cipta.

\section{Saran}

Hasil penelitian mengenai pengaruh kepemimpinan (X1) dan motivasi kerja (X2) terhadap produktivitas kerja (y) pada karyawan PT. Trimuri Karya Cipta, maka saran yang disampaikan antara lain :

1. Melakukan penelitian dengan menggunakan analisa jalur, karena penelitian ini terlalu sederhana hanya melihat pengaruh kepemimpinan dan motivasi kerja terhadap produktivitas kerja karyawan secara partial. Hal ini dikarenakan interaksi kedua variable bebas dapat mempengaruhi baik secara langsung maupun tidak langsung terhadap produktifitas kerja karyawan pada PT. Trimuri Karya Cipta.

2. Perlu ada penelitian lebih lanjut dan lebih luas cakupannya, dikarenakan ada pengaruh yang sedang atau lemah dalam meningkatkan produktifitas kerja karyawan dan sementara faktor - faktor lain diketahui lebih dominan dalam mempengaruhi produktivitas kerja karyawannya pada PT. Trimuri Karya Cipta. 
3. Penelitian selanjutnya diharapkan dapat juga melakukan peninjauan dan observasi yang lebih luas areanya, dimana tidak hanya karyawan bagian produksi saja pada PT. Trimuri Karya Cipta saja, sehingga dapat mendapatkan hasil yang lebih representatif.

\section{Daftar Pustaka}

Amirullah. 2015."Pengantar Manajemen Fungsi Proses Pengendalian”. Jakarta : Mitra Wacana Media.

Hamali, AY. 2013. Pengaruh Motivasi terhadap Produktivitas Kerja (studi kasus pada PT. Stars Part Bandung). Jurnal The Winners 14(2): 77-86.

Handoko T, Hani. 2011. “Manajemen Sumber Daya Manusia”. Yogyakarta : BPFE.

Harimisa, M. 2013. Kepemimpinan dan Motivasi Kerja Pengaruhnya terhadap Produktivitas Kerja pegawai dikantor camat sario Kota Manado Jurnal. EMBA. 1(4) : 2143-2154.

Kaswan. 2015. Pelatihan dan Pengembangan. Bandung: Alfabeta.

Ketut, G. 2016. Sumber Daya Manusia. Edisi 1. Cv. Andi Offset. Yogjakarta.

Laksamiari, P. 2019. Pengaruh Motivasi Kerja terhadap Produktivitas Kerja Karyawan pada Perusahaan Teh Bungan Teratai. Jurnal Pendidikan Ekonomi 11(1).

Latif, A. 2015. Pengaruh Gaya Kepemimpinan dan Motivasi terhadap Produktivitas Kerja Karyawan PT. Monopoli Raya Kabupaten Langkat. Jurnal Manajemen dan Keuangan 4(1).

Mamik. 2016. Sumber Daya Manusia. Edisi 1. Zifatma Jawara. Sidoarjo.

Mangkunegara, A.A Anwar Prabu 2012. "Manajemen Sumber Daya Manusia Perusahaan”. Bandung : PT. Remaja Rosdakarya'

Nawawi, Hadari. 2012."Kepemimpinan Yang Efektif. Yogyakarta : UGM Press.

Rampisela VA dan Lumintang GG. 2020. Pengaruh Motivasi Kerja, Lingkungan Kerja dan Upah terhadap Peningkatan Produktivitas pada PT. Daya Cipta. Jurnal EMBA. 8(1).

Rivai,Veithzal dan Sagala, Ella Jauvani 2011. Manajemen Sumber Daya Manusia untuk Perusahaan dan Teori ke Praktik. Jakarta: PT. Raja Gafindo.

S.P, Hasibuan, Malayu. 2013. Manajemen Sumber Daya Manusia. Jakarta : PT. Bumi Aksara.

S.P, Hasibuan, Malayu. 2017. Manajemen Sumber Daya Manusia. Jakarta: PT. Bumi Aksara.

Satriadi, D. 2017. Pengaruh Gaya Kepemimpinan dan Motivasi terhadap Produktivitas Kerja pada Bank BRI Tanjung Pinang. Jurnal Benefita 2(1) : 34-46.

Siagian, Sondang.P. 2014 “Kiat Meningkatkan Produktivitas Kerja”. Cetakan Kedua. Jakarta : PT. Rineka Cipta. 
Sinungan, Murchadarsyah. 2014. Produktivitas : Apa dan Bagaimana. Jakarta: Bumi Aksara.

Sugiyono. 2014. “Metode Penelitian Bisnis”. Bandung : Alfabeta.

Sugiyono. 2017. Statistik untuk penelitian. Edisi Kedua Puluh delapan. Bandung. CV Alfabeta.

Sunyoto, Danang. 2015. "Penelitian Sumber Daya Manusia". Jakarta : CAPS (Center of Academic Publishing Service)

Sutrisno. Edy. 2011. Manajemen Sumber Daya Manusia. Jakarta : Kencana Prenada Media Group

Thoha, Miftah. 2010. “Kepemimpinan dan Manajemen”. Jakarta : Rajawali Pers.

Wahyuningsih, S. 2019. Pengaruh Pelatihan Dalam Meningkatkan Produktivitas Karyawan. Jurnal Warta. 60 : ISSN 1829-7463.

Wibowo, 2016, Manajemen Kinerja, Edisi kelima, Jakarta : Rajawali Pers.

Wijono, S. 2018. Kepemimpinan dalam prefektif organisasi. Edisi 1. Prenadamedia Group. Jakarta.

Sedarmayanti. (2018). Tata Kerja dan Produktivitas Kerja. In Bandung, CV Mandar Мaju. 